\title{
Forças Armadas, Autonomias e Autoritarismo: a atuação das Forças Armadas de Brasil e Chile nas transições rumo à democracia
}

\author{
Victor Augusto Ramos Missiato \\ Instituto Presbiteriano Mackenzie
}

\section{Introdução}

História, memória, esquecimento e revisionismo são aspectos fundamentais para se pensar o modo como as sociedades latino-americanas, que passaram por golpes e regimes militares na segunda metade do século XX, agiram, reagiam, agem e reagem ao se defrontarem com o seu recente passado autoritário. Entre diferentes possíveis momentos para se analisar tais instrumentações políticas, o período das transições nos fornece um material de grande valia para compreender o papel dos atores sociais envolvidos nesses processos, e o modo como a lei e a história, o futuro e o passado, passariam a ser encarados pelas sociedades a partir de então.

No caso dos nossos objetos de estudos aqui apresentados, partimos de uma mesma conjuntura, quando Brasil e Chile, ao final dos anos 1980, realizaram seus processos de transição rumo a um sistema democrático. Por meio dessa perspectiva, procuramos ampliar tal relação inserindo as transições, brasileira e chilena, na quadratura latino-americana, realizando assim, uma análise comparada. Partindo do ano de 1988 como um momento-chave, a partir da vitória do NO durante o plebiscito chileno e da promulgação da Constituição brasileira de 1988, realizaremos um exercício comparativo ao analisar especificamente cada transição e relacioná-las com as conquistas e os problemas referentes a dois processos transitórios que não se concluíram naquele instante e acabaram por preservar políticas ligadas aos tempos ditatoriais, principalmente no que diz respeito às autonomias das Forças Armadas frente ao controle civil. Porém, tal identificação não significou uma dependência integral por parte desses processos frente ao que ocorreu nas demais transições latinoamericanas. Ao invés disso, as experiências no Brasil e no Chile gestaram suas peculiaridades político-culturais e sempre dialogaram com as culturas políticas existentes em seus respectivos países.

Em termos conceituais, cultura política é compreendida aqui como uma visão global de mundo e de sua evolução inserida na própria natureza dos problemas relativos ao poder, compartilhada por um grupo importante da sociedade num dado país e num dado momento da história. Retomando os trabalhos de Serge Berstein, podemos compreender este conceito como uma estreita aproximação entre sistemas políticos e cultura global da sociedade política. Sendo assim, a cultura política é um elemento dessa cultura global (Berstein, 2009, p. 31-33). Trata-se, ademais, de um fenômeno plural, pois falar em cultura política de um país acaba por envolver um conjunto de culturas políticas com raízes filosóficas ou histórias distintas, abarcando concepções opostas de poder e invocando valores antagônicos:

Além disso, é evidente que existem culturas políticas dominantes, porque suas concepções atendem diretamente às aspirações majoritárias da sociedade, porque elas parecem traduzir os anseios da maioria e porque elas oferecerem respostas 
aparentemente pertinentes para os problemas do momento. Ademais, seu poder de atração é tal que elas chegam a influenciar culturas políticas vizinhas (Berstein, 2009, p. 37).

Por conseguinte, ao realizarmos um exercício comparativo entre esses dois processos estamos, no fundo, procurando identificar as diferentes estratégias construídas no espaço latino-americano a partir de distintas interpretações acerca das transições vivenciadas no Brasil e no Chile. Esse exercício ganha maior relevo, quando o colocamos na perspectiva da chamada "terceira onda" (1974-1991) de democratização, termo esse cunhado por Samuel Huntington (1994). Ademais, por estar inserida nesse movimento internacional, as estratégias de transição balizaram a visão de mundo dos nossos dois objetos de estudo. A fim de problematizarmos as relações entre as esferas nacionais, regionais e globais, faremos uso da chamada "História Comparada Problema". Tal abordagem

corresponde a uma nova dimensão que se acrescenta à história, o que a eleva da dimensão mais limitada da "linha" para a dimensão mais complexa do plano. Contudo, por ser comparada - vale dizer, por envolver a comparação entre dois recortes unidos por um problema em comum, a "História Comparada" problematizada termina por avançar para uma configuração ainda mais complexa que articula dois ou mais planos, o que a introduz em uma terceira dimensão (se quisermos continuar investindo na ideia de representar visualmente este tipo de história) (D’Assunção Barros, 2014, p. 57).

Além de ampliar o campo dimensional da pesquisa, relacionando as estratégias de transição, essa análise comparada possibilita "observar dois objetos ou realidades dinâmicas em transformação" que partem tanto para uma direção mais específica quanto para a construção de um "conjunto referente, que vai sendo construído quer pela investigação quer pelas instâncias do pensamento crítico" (Aggio, 2015, p. 145).

\section{A sociedade chilena em tempos de transição}

Em 2018, segundo Martina Lagos, diretora do instituto de pesquisa Latinobarómetro, sediado em Santiago de Chile, em entrevista ao periódico El País, a confiança na democracia latino-americana viveu um annus horribilis. Segundo o instituto, o apoio dos cidadãos ao sistema democrático chegou ao índice de $48 \%$, registrando o pior nível desde 2001, quando a região vivia um período de baixo crescimento econômico, crises inflacionárias e dificuldades relacionadas ao pagamento das dívidas externas. Consonantemente, o atual enfraquecimento do apoio à democracia por parte dos latinoamericanos caminha em paralelo a uma queda vertiginosa na produção das riquezas nacionais, diante novamente dos baixos crescimentos do Produto Interno Bruto (PIB) de seus principais países ${ }^{1}$. Frente a essa conjuntura atual, o apoio a governos e partidos, identificados com uma histórica relação com o desenvolvimento democrático na região, também sofreram com a perda de apoio popular. Embora exista uma importante literatura científica que minimiza a interação entre democracia e conjuntura

\footnotetext{
${ }^{1}$ Entre os anos 2015 e 2020 o crescimento da região latino-americana e o Caribe ficará abaixo de 1\% ao ano, praticamente, com estagnação da renda per capita (Alves, 2019).
} 
econômica diante da relação entre cidadão, política e Estado, não podemos nos distanciar dessa questão, principalmente quando analisamos sociedades imersas às chamadas economias de mercado, quando a figura do consumidor exerce um papel central nas escolhas políticas de seus representantes. No caso da história recente do Chile, tema deste presente artigo, tal discussão se faz presente em nosso objeto de estudo, quando nos deparamos com uma história que está intrinsecamente arrolada entre o desenvolvimento de uma economia neoliberal em associação a um governo marcadamente ditatorial e personalista (1973-1990), liderado sob o regime do general Augusto Pinochet.

Desde o início do governo Pinochet, havia um discurso programático que procurava inviabilizar, pelo menos naquele momento, um retorno a uma ordem democrática no país. Ao contrário do caso brasileiro, por exemplo, quando havia um discurso em favor do golpe de 1964 no que tange a defesa de uma ordem democrática em favor de uma suposta luta anticomunista, no Chile, havia uma direção clara de "salvar o Chile do comunismo" e estabelecer uma nova ordem política e social:

O notável é que o discurso dos golpistas no Chile assumiu o mesmo tom do discurso revolucionário que fazia a Unidade Popular, instituindo, entretanto, um vetor contrário: passa-se a postular uma contrarrevolução por meio de métodos revolucionários. $\mathrm{O}$ anseio não era o retorno à democracia (embora por algum momento alguns setores golpistas tenham vocalizado essa perspectiva), mas a imposição de uma ditadura que reconstruísse o país (Aggio, 2015, p. 152).

O regime pinochetista tratou de inviabilizar o retorno ao sistema democrático ao romper com a estrutura política estabelecida desde os anos 1920. De acordo com o historiador Alberto Aggio "o golpe de 1973 foi, em suma, um ato cirúrgico de cancelamento da política entre os chilenos, o que significava dizer que foi a supressão da forma pela qual a sociedade chilena compreendia-se a si mesma" (Aggio, 2015, p. 152). O cancelamento também se deu através da eliminação da vida política. Em um famoso trecho do livro "O que é isso, Companheiro?", o jornalista Fernando Gabeira relatou um momento no Chile, no ano de 1973, em que ao caminhar pela avenida Irarrásaval, notória por sua dificuldade em pronunciá-la, visualizou um "caminhão cheio de cadáveres". Iniciava-se, assim, uma ditadura que marcaria uma ruptura na história da sociedade chilena.

A partir de setembro de 1973, estabeleceu-se no Chile uma ditadura de caráter extremamente personalista, com baixo índice de institucionalização. Quase todos os processos decisórios, de âmbito administrativo e político, ficaram centralizados sob comando de Pinochet. Crítico voraz do sistema democrático chileno (1925-1973), o governo Pinochet compreendia que somente um corte revolucionário nessa estrutura poderia fomentar no país um processo de modernização capitalista, onde o Estado exerceria um papel tutelar e repressivo, ao passo em que a economia chilena seria conduzida por um programa de reformas marcadamente neoliberais, no campo das empresas públicas, serviços de saúde e previdência social (Aggio, 2015, p. 153-154).

$\mathrm{O}$ aparato jurídico-administrativo que respaldou o programa de governo pinochetista ganhou materialidade a partir do processo de formulação da Constituição, em 1980, pois diagnosticou-se, por parte dos militares, que a crise não era apenas de governo, mas de regime. De acordo com os novos agentes governamentais, a Constituição de 1925 não conseguiu proteger a democracia chilena do marxismo e dos políticos populistas (Valenzuela, 1997, p. 4). Desse modo, haveria que se refundar a 
cultura política chilena, suspendendo processos eleitorais, a atuação do Congresso Nacional, bem como deslocando do poder a atuação dos partidos políticos. Tamanha transformação só foi possível graças à concentração de poder estabelecida pelo Gen. Pinochet. Trata-se de um regime militar que se prolongou por dezesseis anos, liderado sempre por um presidente que se colocou como superior também na hierarquia militar.

Dentre os anos 1980 e 1988, Pinochet governou o país por meio de uma Junta Militar, que continuaria implementando seu projeto neoliberal, ao mesmo tempo em que preparava o Estado chileno para se adequar à nova Constituição. Esperava-se que o Plebiscito de 1988 apenas legitimaria o projeto político pinochetista. Ocorrido no dia 05 de outubro de 1988, o Plebiscito Nacional de Chile propunha uma votação acerca da continuidade do regime político liderado por Pinochet por mais oito anos. Participaram da votação mais de sete milhões de chilenos e o resultado dos votos válidos foi de $43 \%$ pela continuidade do regime e $54 \%$ pelo fim da ditadura. A derrota surpreendente mobilizou a sociedade chilena em prol do retorno às eleições e a vida democrática. Porém, o regime pinochetista não abandonou o poder de imediato. Vê-se, portanto, que a transição no Chile se deu através de um compromisso político, conduzido pelo pinochetismo, desde o seu início. Essa constatação corrobora com uma sólida posição historiográfica acerca do que nós podemos chamar de a qualidade da transição à democracia no Chile. Visto como um país-exemplo na América Latina, o Chile, durante os primeiros anos do processo de transição, foi visto como um modelo importante para a região. Acreditava-se que a transição ocorrera de forma satisfatória, fortalecendo o processo democrático. A mudança de perspectiva em torno do processo de transição democrática no Chile começou a mudar em meados dos anos 1990, quando alguns acontecimentos abalaram as estruturas do emergente regime:

Inicialmente político-jurídica, mas rapidamente histórico-política, a controvérsia vem se notabilizando pela emergência de uma multiplicidade de posições revisionistas que não apenas resolveram questionar as interpretações em voga sobre a ditadura de Augusto Pinochet (1973-1990) como também passaram a se concentrar, de maneira especial, no processo de transição vivenciado pelo país; muitas destas posições revisionistas têm ampliado sua postura crítica inclusive em relação aos governos democráticos que tomaram posse depois de março de 1990 (Aggio, 1999, p. 39).

Por conta desses acontecimentos que iremos abordar posteriormente nesse texto, constituiu-se uma visão prevalecente que alude ao fato de que a transição chilena passou a ser vista como uma transição incompleta. Analisando o período da transição chilena, Alberto Aggio afirma que o país passou da ditadura à democracia de má qualidade. Apesar de todos os crimes e perseguições cometidos durante a ditadura, enfrentando protestos em massa ao longo da década de 1980, ocasionando grandes embates entre os anos 1983 e 1986, o pinochetismo conseguiu assegurar que nenhuma mudança significativa ocorresse no itinerário constitucional ratificado em 1980:

Superando ventos e tempestades, em águas permanentemente turvas em função das pressões internas e internacionais, Pinochet manteve a habilidade de forçar a todos os seus adversários que buscavam sua renúncia sem condições ou sua saída por meio de uma pretensa negociação cívico-militar, a insertar-se no itinerário legal criado 
pelo regime, que incluía uma série de procedimentos, rigidamente pautados por um conjunto de leis políticas elaboradas sem nenhum diálogo com a oposição moderada. O processo incluía os seguintes passos: inscrição nos novos registros eleitorais, formação de partidos políticos, aceitação de um sistema binominal majoritário (único no mundo), consumação do plebiscito sucessório em outubro de 1988 e realização de eleições parlamentares - e eventualmente presidenciais - em 1989 (Aggio, 2000, p. 89).

O sentimento de desilusão espraiou-se na opinião pública chilena dos anos 1990, quando o pinochetismo fora conseguindo guardar posição no establishment político. Devido ao processo de negociações envolvendo situação e oposição durante a transição democrática no Chile, a manutenção da Constituição de 1980 possibilitou que Pinochet se transformasse em senador vitalício, pois graças a um artigo presente na Carta, todos os presidentes adquiririam esse direito depois de terminarem seus mandatos. Embora tenha perdido o plebiscito de 1988, o general chileno manteve-se no cargo de presidente por mais um ano e meio, podendo efetuar uma transição controlada, sem grandes rupturas.

A transição, portanto, marca um tipo de transformação que não se associa a um processo revolucionário, conforme analisa Manuel Garretón. Trata-se de analisá-la por meio de mecanismos que complementam seu processo, como enfraquecimento da legitimidade do governo autoritário, mobilizações populares em favor de políticas de transformação na esfera institucional e constitucional, espaços de debates e acordos entre titulares do poder e oposição democrática, além de instrumentos de ação e mediação que facilitem ou dificultem a transição (Garretón, 1992, p. 61). Diante desses apontamentos, Garretón destaca o duplo significado que a derrota política no Plebiscito de 1988 conferiu ao pinochetismo, quando o regime ditatorial perde sua projeção de poder na sociedade chilena, ao mesmo tempo em que assegura o controle do tempo da transição, através de mecanismos estabelecidos previamente pelo regime (Garretón, 1992, p. 63).

Visto por uma perspectiva ampliada, somos influenciados a perceber tal fenômeno por meio de um estado de latência como origem do presente, conforme nos orienta Hans U. Gumbrecht, quando procura pensar a sociedade emergente no pós-Segunda Guerra Mundial. Debruçando-se acerca do processo de "desnazificação" na Alemanha, Gumbrecht visualiza no trabalho do escritor sueco Stig Dagerman, quando escreveu suas impressões da sociedade alemã logo após o conflito, a perplexidade em relação à ausência de "paixão e a dedicação necessárias para detectarem e punirem os crimes do passado", quando os juristas germânicos não exerceram o devido julgamento junto aos responsáveis pelos crimes cometidos durante o nazismo. Ciente de que o nazismo não mais exerceria sua projeção de poder, Gumbrecht nos apresenta uma provocação inquietante enquanto a relação da sociedade com sua memória e esquecimento:

O tempo - hoje e para nós - parece revelar uma nova estrutura e se desdobrar num ritmo que é diferente do tempo "histórico" que governou o século XIX e o começo do XX. Neste novo cronótopo - para o qual ainda não existe nome, apesar de vivermos dentro de suas formas - a agência, a segurança e o progresso histórico da humanidade desapareceram numa memória distante. Apenas nos restam o desejo não redimido, a incerteza e a desorientação. Ao mesmo tempo, ameaça-nos um futuro que jamais escolhemos (Gumbrecht, 2014, p. 62). 
O caráter pactuante da transição chilena não fez desaparecer nem os fatos e nem a memória dos acontecimentos, mas o sentimento de justiça em relação aos crimes cometidos durante a ditadura chilena foi dando lugar a uma "atmosfera de latência":

É impossível dizermos com precisão de onde nos vem a certeza dessa presença, tampouco sabemos afirmar exatamente onde está agora aquilo que é latente. E, porque não conhecemos a identidade do objeto ou da pessoa latente, nada nos garante que reconheceríamos essa entidade se alguma vez viesse a revelar-se diante de nós. Além do mais, aquilo que está latente sofre transformações durante o tempo em que permanece oculto (Gumbrecht, 2014, p. 40).

Para além do apoio de parte da sociedade chilena aos legados do pinochetismo, que mesmo diminuindo no decorrer das décadas de 1990 e 2000, manteve uma porcentagem significativa, a própria ação majoritária da oposição democrática chilena corroborou para esse estado de latência. Desde a campanha plebiscitária contra a continuidade do governo Pinochet, em 1988, a estratégia adotada procurou distanciar-se do passado recente ao desenvolver uma campanha voltada para frente, desassociando o os tempos de tortura e os sentimentos gestados com isso e a perspectiva de mudança de regime sem maiores traumas. Prova disso encontra-se no hino Alegria ya viene, composto por Jaime de Aguirre e escrito por Sergio Bravo. Em entrevista à CNN Chile, em outubro de 2018, Jaime de Aguirre afirmou que o objetivo era criar uma melodia alegre e otimista, sendo alegre, inclusiva, transversal e aberta. Vitoriosa, tal estratégia nos diz muito sobre a latência que envolveu o processo de transição no Chile.

\section{A crise de identidade da missão militar no Brasil da redemocratização}

Diferentemente da trajetória histórica chilena, na história republicana brasileira as relações entre militares e civis se deram, em muitos momentos, por meio de disputas políticas dentro do controle do poder político no Brasil e também, em torno da manutenção do domínio das Forças Armadas gerenciando a Defesa no país. Quando falamos em um pensamento na esfera da Defesa no Brasil temos que ter em mente como e quando houve a construção desse tema, o qual apesar de tratar-se de uma questão nacional, historicamente não foi algo construído pela sociedade brasileira. A partir desse cenário, nota-se que a condução dessas políticas foi realizada por grupos estritamente ligados a uma função específica, sem a presença ativa da população ou dos representantes dessa sociedade, em inúmeras situações.

No século XX, a perspectiva se consolidou no que diz respeito à presença militar no ambiente político brasileiro. A criação da Escola Superior de Guerra (ESG) em 1948 representou o pilar dessa construção ideológica. Influenciada pelo War College norte-americano, essa instituição serviu de apoio para a construção de um projeto político, cuja principal finalidade era levar o Brasil ao status de "grande potência". Esse órgão também esteve ligado a Doutrina de Segurança Nacional 
implementada pelos estadunidenses visando o combate ao comunismo, durante o início da Guerra Fria $^{2}$.

Um dos fundadores da ESG foi Golbery do Couto e Silva, responsável também pela formação de um pensamento geopolítico brasileiro. Boa parcela do pensamento em Defesa no Regime Militar (1964-1985) está vinculada ao conceito estratégico nacional que se faz presente na geopolítica de Couto e Silva. Dentro das relações civis-militares, visualizamos a participação civil ou falta dela no que tange o apoio e/ou a conivência para com os generais, os quais governaram ininterruptamente o Brasil por mais de duas décadas, na segunda metade do século XX. Dada essa situação vigente durante boa parte do Regime Militar (1964-1985), destacamos que o processo de redemocratização do Brasil não foi orientado apenas por mãos civis, pois assuntos que deveriam ser tratados na Constituição de 1988 não foram dialogados e tais mudanças não foram discutidas, pois na prática eram ações que minimizariam a abrangência dos interesses do aparelho militar. Apesar de manterem o controle político sobre as questões de Defesa e também, segurança interna, os militares tiveram que passar por uma reorientação de suas prioridades e ameaças.

A presença militar no que tange a interferência na política do país permaneceu após o regime militar. Podemos constatar dessa presença, uma permanência dos assuntos ligados a Defesa e Segurança no país sob as mãos das instituições castrenses. Após o lobby militar dado na formação da Constituição de 1988, a década de 1990 surge com novos desafios para as Forças Armadas do Brasil. Apesar de manterem o controle nas políticas de Defesa, as instituições militares passaram pelo seguinte desafio: a procura de uma nova missão nos âmbitos interno e externo (Santos, 2004).

Pode-se afirmar que houve uma crise de identidade dos militares referente à sua atuação em um regime democrático. Vale notar que foram mais de duas décadas em que os militares estiveram no poder comandando o país. Contrapondo-se ao período da Guerra Fria, podemos constatar que os militares no que se refere a sua missão interna se orgulhavam de participar em auxílios sociais, que os próprios denominavam "atividades subsidiárias". Todavia, como o próprio nome nos fala, essa função se caracterizou por ser algo secundário no pensamento militar para sua missão interna. O que realmente incomodou as Forças Armadas nesse período de transição foi uma possível mudança estrutural para se transformarem em apenas forças policiais agindo no território nacional.

Essa tendência teria se mostrado clara a partir de 1990 na Cúpula de Londres, quando ocorreu a reconfiguração estratégica da Organização do Tratado do Atlântico Norte (Otan). Essa nova perspectiva trazia consigo a necessidade de haver uma maior cooperação militar entre os países, abrangendo um contingente menor de tropas, as quais deveriam buscar uma maior mobilidade e também, flexibilidade. Dentro dessa visão, os conflitos passariam a ser locais e/ou regionais em detrimento de um conflito de grande escala.

\footnotetext{
${ }^{2}$ De acordo com o Centro de Pesquisa e Documentação de História Contemporânea do Brasil (CPDOC), “Os militares envolvidos no golpe de 1964 justificaram sua ação afirmando que o objetivo era restaurar a disciplina e a hierarquia nas Forças Armadas e deter a "ameaça comunista" que, segundo eles, pairava sobre o Brasil. Uma ideia fundamental para os golpistas era que a principal ameaça à ordem capitalista e à segurança do país não viria de fora, através de uma guerra tradicional contra exércitos estrangeiros; ela viria de dentro do próprio país, através de brasileiros que atuariam como "inimigos internos" - para usar uma expressão da época. Esses "inimigos internos" procurariam implantar o comunismo no país pela via revolucionária, através da "subversão" da ordem existente - daí serem chamados pelos militares de "subversivos". Diversos exemplos internacionais, como as guerras revolucionárias ocorridas na Ásia, na África e principalmente em Cuba, serviam para reforçar esses temores. Essa visão de mundo estava na base da chamada "Doutrina de Segurança Nacional" e das teorias de "guerra anti-subversiva" ou "anti-revolucionária" ensinadas nas escolas superiores das Forças Armadas” (FGVCPDOC, 2019, s.p.).
} 
Essa nova realidade oferecida pelo governo dos EUA e seus aliados trouxe questionamentos por parte dos países latino-americanos. Ou seja, os militares indagavam acerca do real interesse que estaria por trás disso, mesmo sabendo que a América Latina depois da Guerra das Malvinas (conflito entre Argentina e Inglaterra) não presenciou qualquer conflito maior ou da mesma intensidade em seu território. Então, por que motivo manter grandes contingentes militares na região? Importante lembrar que sempre houve uma histórica desconfiança por parte dos militares brasileiros ao olharem para cima e visualizarem a potência norte-americana com sua influência/interferência em todo continente.

Nesse cenário, qual foi a nova missão das Forças Armadas brasileiras? Quais os novos inimigos a serem enfrentados nessa nova Ordem Mundial?

Para avançarmos nessas questões, temos que ter em mente que o papel das Forças Armadas brasileiras ainda não estava claramente definido, ou melhor dizendo, suas funções não estariam restritas ao âmbito externo ao final do século XX:

Uma outra questão que deve ser considerada é a separação entre os conceitos "política de defesa" e "segurança interna". Tradicionalmente, esses conceitos constituem domínios distintos: a política de defesa tem orientação externa e é tarefa das Forças Armadas, enquanto a segurança interna pertence à área da polícia. [...] O Brasil apresenta uma situação mista. Enquanto o conceito de segurança nacional está ausente da Constituição de1988 e as polícias civil e militar estão claramente incumbidas da segurança pública (art. 144), o papel das Forças Armadas é definido de maneira ambígua (Santos, 2004, p. 119).

De acordo com o art. 142 da Constituição de 1988, as Forças Armadas são responsáveis por defender a pátria, garantir os poderes constituídos e, se solicitadas pelo Presidente da República, garantir também a lei e a ordem. No entanto, a garantia da lei e da ordem atribuída às Forças Armadas resultou num legado antidemocrático quanto ao processo de redemocratização no Brasil, logo após sua aprovação. Ao invés de atuarem como instrumento da sociedade no uso da força ante uma ameaça externa, as Forças Armadas adquiriram o direito de utilizar essa força contra seu próprio povo e exercer um poder político interno, um poder de polícia. Apesar da suposta submissão à autoridade suprema na figura do líder do Executivo, o Congresso, em 1988, também conferiu aos poderes Legislativo e Judiciário o direito de convocar as Forças Armadas para intervirem em casos de crise interna. No fim do mesmo o ano já colher-se-ia o resultado funesto dessa medida.

No dia 07/11/1988, trabalhadores da Companhia Siderúrgica Nacional (CSN), localizada na cidade de Volta Redonda (RJ), entraram em greve reivindicando melhores condições socioeconômicas. Dois dias depois, o juiz da terceira Vara Cível de Volta Redonda, Moises Cohen, redigiu um mandato de manutenção de posse e solicitou ao Exército, juntamente com a Polícia Militar, a reintegração da CSN. Soldados especializados no aniquilamento do inimigo em uma guerra, o grupo militar, comandado pelo general José Luis Lopes, realizou com "maestria" sua função e matou três grevistas. Em entrevista, o general Lopes afirmou que possuía dois motivos para atuar no evento: "para reestabelecer a ordem porque houve insubordinação civil e para preservar o patrimônio que até agora não sofreu danos". O episódio ficou conhecido como "Massacre de Volta Redonda". Devido às repercussões negativas, tanto dentro quanto fora do meio castrense, o Congresso aprovou em 23 de julho de 1991, a Lei Complementar n. 69, a qual permitia apenas ao Executivo definir a 
atuação das Forças Armadas em missões internas. Os líderes do Senado, Câmara de Deputados e Supremo Tribunal Federal poderiam requerer esse direito, porém o Presidente é quem autorizaria ou não esses pedidos.

Essa garantia transformada em ambiguidade no papel das Forças Armadas veio auxiliar na "crise de identidade" dos militares e sua nova missão. O fim da Guerra Fria e o processo de redemocratização dos países latino-americanos causaram uma desorientação aos militares brasileiros. Contudo, nota-se que desde os tempos de Regime Militar já havia uma crise de identidade interna no meio militar (Coelho, 2000).

Após a Ditadura Militar (1964-1985) no Brasil, iniciou-se um processo de redemocratização das instituições nacionais, tendo essa transição ocorrida de maneira pacífica, tanto que no governo Sarney vários militares "auxiliaram" nesse processo, e até participaram de forma indireta na constituição de 1988 (lobby militar) (Zaverucha, 1994). Tanto o desinteresse da população e de seus representantes no poder, quanto a participação dos militares em não perderem seus espaços na condução dessas políticas (exemplo: o lobby militar em 1988) travaram a formação de uma política de defesa alicerçada nos interesses nacionais vinculados ao regime democrático, assim que esse esteve vigente ao término do regime militar.

\section{A transição: avanços e percalços no Chile}

Para Garretón, se partirmos do pressuposto de que o plebiscito de 1988 culminou no desencadeamento do processo de transição, tal acontecimento não delimita sua conclusão, embora apresente importantes caminhos a serem trilhados (Garretón, 1992, p. 64). Logo após o plebiscito, o núcleo "duro" do governo Pinochet deixou o poder, assim como o aparato militar também deu início a volta aos quartéis. Essa retirada teve um efeito similar ao que ocorreu no caso brasileiro, quando este ficou conhecido por estabelecer uma transição "lenta, gradual e segura". Os militares chilenos também salvaguardaram alguns direitos criados durante a ditadura, mantendo assim, uma importante autonomia afastada dos princípios democráticos do controle civil sobre os militares. Dentre as políticas de controle militar sobre o Estado e a sociedade chilena estiveram as políticas de redução do controle do Estado sobre a economia, as leis orgânicas constitucionais a exemplo daquela que consagra a autonomia do Banco Central, da Televisão, das Forças Armadas etc., e as medidas que asseguram aos membros do pinochetismo os cargos da administração pública, das reitorias nas universidades, do Poder Judiciário e, em particular, dos altos comando do Exército (Garretón, 1992, p. 66).

Por parte da oposição, vitoriosa no plebiscito de 1988, sua estratégia também acabou gerando um duplo significado, segundo Garretón. Primeiramente, coube aos oposicionistas democráticos converter a coalizão vitoriosa em um governo de concertação, desenvolvendo assim, um pacto entre diferentes correntes político-ideológicas, que sempre estiveram em confrontação antes do golpe de 1973. Posteriormente, caberia a Concertación assegurar um programa que completasse a transição em termos constitucionais, embora ao longo desse processo os limites ficariam clarividentes (Garretón, 1992, p. 69).

Houve, por parte do estamento militar, uma série de "leyes de amarre". Dentro desse pacote de autonomias, promulgou-se uma lei referente às Forças Armadas, que deixaria o controle presidencial 
sobre os militares em uma situação muito difícil ao impossibilitá-lo, por exemplo, de destituir os comandantes em chefe das diversas Armas (Calbún, 2012, p. 13).

Subjaz disso, uma configuração política que amorteceu o alcance da redemocratização chilena em toda a sua sociedade. Tendo como base o enorme poder exercido pelos militares, quando estes abandonaram o governo, as instituições permaneceram atreladas a um texto constitucional autoritário (Agüero, 2006, p. 316). Diferentemente de outros países sul-americanos, o Chile não alterou sua constituição no processo transitório. No que diz respeito às semelhanças, os casos brasileiro e chileno guardam consigo a preservação das autonomias e prerrogativas no controle sobre a defesa nos dois países:

Tanto no Chile como no Brasil o poder das forças armadas para enfrentar a transição e continuar a exercer uma enorme influência nos regimes democráticos sucessórios, baseou-se, entre outros fatores, no alcance de uma maior institucionalização, que teve maior expressão na Constituições aprovadas durante as ditaduras. Essa institucionalização, que por um bom tempo resolveu o dilema da sucessão presidencial, que influenciou nos outros regimes militares na região, possibilitoulhes enfrentar a transição com relativa unidade superior e com recursos normativos de poder para resistir às demandas democratizantes da oposição (Agüero, 2006, p. 316 , tradução do autor).

Contudo, o debate em torno das constituições ultrapassa a esfera da defesa, pois a própria cultura política tem um total vínculo com a carta de direitos e deveres de um cidadão. Desse modo, segundo Carlos Huneeus, no Chile pós-Pinochet, a constituição seguiu o modelo de "democracia protegida", considerada uma alternativa à "democracia liberal". Segundo o autor, este tipo de constituição adotou princípios opostos ao constitucionalismo democrático, apesar de a oposição lutar por mudanças no texto constitucional, conquistando espaços limitados (Huneeus, 2014, p. 159).

A limitação em aprofundar o processo de democratização na transição chilena fomentou o debate em torno dos chamados enclaves autoritários (Garretón, 1989). Mecanismos que travam o avanço das políticas democráticas em um contexto de transição, os enclaves foram qualificados a partir de três tipos: 1) institucional: elementos normativos, constitucionais e legislativos - limitam o poder da vontade popular, o princípio de representação e mantêm as prerrogativas das Forças Armadas acima do poder político civil; 2) ético-simbólico: permanência dos efeitos das violações dos direitos humanos em contextos de ditadura, luta armada ou guerra civil. Incapacidade de fazer justiça; 3) dimensão dos sujeitos políticos: adequar o regime democrático aos princípios e orientação das ditaduras precedentes (Garretón apud Aggio, 1999, p. 53-54).

Em relação ao enclave institucional, Garretón seleciona tanto os elementos presentes na Constituição de 1980, que se mantiveram vigentes na democracia, como instituições que não se adequaram totalmente ao novo tempo, dentre elas, as Forças Armadas chilenas. Havia, segundo o historiador, uma bunkerização por parte de Pinochet e seu grupo (Garretón, 1989, p. 77). Excessivas autonomias e prerrogativas foram conferidas ao pinochetismo, sem que houvesse um contrabalanceamento referente aos julgamentos e condenações referentes às violações aos direitos humanos cometidos entre os anos 1973- 1988.

No que diz respeito ao enclave ético-simbólico, a questão dos direitos humanos passa a ser central, pois defrontava-se ali na conjuntura de transição um confronto ético, expresso nos 
movimentos em favor dos direitos humanos versus a lógica político-estatal (Garretón, 1989, p. 78). Aprofundando este tema para além do caso chileno, podemos perceber como o aparato estatal esforçou-se para assegurar sua hegemonia na substituição da violência física pela violência douce nos casos de transição:

A violência ilegal do Estado e a impunidade da violência por parte dos cidadãos continua depois das transições políticas, mascarada pela retórica democrática, dissimulando relações fundamentais de força intocadas. As "instituições da violência" (Franco Basaglia), como a tortura, o racismo, as instituições totais prisões e manicômios -, os aparelhos repressivos, não são transformados pelas transições, mesmo depois de constituições democráticas (Pinheiro, 1991, p. 45).

O fato de a transição ter sido orientada pelo regime pinochetista possibilitou que muitas das instituições políticas chilenas mantivessem o caráter autoritário do governo anterior. Ademais, o governo concertacionista não se utilizou de uma conjuntura favorável para derrubar os enclaves institucionais autoritários, desnudando uma "ausência de prioridades e estratégia" (Garretón, 1989, p. 87). Esse tipo de atitude abriu margem para que o projeto político da ditadura estivesse posto como um modelo viável e que, ao invés de ser destruído, conquistou espaços não condizentes com um regime democrático em construção.

\section{A transição no Brasil: a Constituinte de 1988 e as autonomias militares}

Ativado o projeto de distensão no governo Geisel e amortecida as pressões internas da linha dura, caberia aos governos militares negociar junto à oposição atuante na esfera político-institucional, uma transição sem grandes impactos, ou seja, uma transição pactuada. Coube a Golbery o planejamento para alijar das negociações políticas as partes radicais das duas forças. O general solicitou ao partido Movimento Democrático Brasileiro (MDB) que abafasse suas alas mais radicais, que se negavam a dialogar com o governo.

O sucessor de Geisel na Presidência, Gen. Figueiredo, manteve o processo de distensão nas mãos das Forças Armadas. Entretanto, através de pressões advindas da sociedade civil, um novo elemento surgiu e influenciou tal processo. Promulgada em 28 de agosto de 1979, a Lei de Anistia apresentou-se como medida de encerramento das penas aos acusados de "subversão", proporcionou a volta de presos exilados, retirou das prisões indivíduos que foram detidos como "inimigos do Estado", libertou os militares de possíveis crimes cometidos, entre eles a tortura, além de ter restaurado direitos políticos e sociais; e, assim, arranjou-se uma anistia "ampla, geral e irrestrita" nos moldes conservadores dessa transição ${ }^{3}$. Ou seja, a partir da Lei de Anistia, os militares não sofreriam

\footnotetext{
${ }^{3}$ Transcorridos 36 anos desde a sua adoção, a Lei de Anistia continua gerando discussões acerca de sua aplicabilidade, visto que alguns de seus artigos geram polêmica devido à suscetibilidade a opostas interpretações. Durante os últimos meses de 2008, a questão da Anistia foi amplamente debatida no cenário político nacional, gerando rachas entre os próprios integrantes do governo, que divergiram quanto à amplitude da Lei em relação aos militares, acusados de cometerem torturas contra presos políticos durante o regime militar brasileiro (1964 a 1985) e, também, as Forças Armadas, as quais alegam que a lei não devia ser alterada. Como forma de comparação, a abertura de inquéritos e a conclusão de julgamentos sobre esse tipo de infração cometida em outros regimes militares na América do Sul, durante o mesmo período que o caso brasileiro, ocorreu e continua acontecendo na Argentina e no Uruguai, por exemplo.
} 
julgamentos após sua volta aos quartéis, pois estavam salvaguardados os direitos a não penalização por ações cometidas durante o regime.

Paralelamente, a fim de conter a ala mais radical dos militares, houve um acontecimento de proporções graves, que gerou uma negociação para que se diminuíssem, significativamente, as pressões exercidas pelos duros. $\mathrm{O}$ fracassado atentado ao Riocentro na cidade do Rio de Janeiro, no dia 30 de abril de 1981, véspera comemorativa do Dia do Trabalhador, serviu de base para o governo Figueiredo silenciar os colegas revoltosos com o então processo transitório:

Este episódio tem uma importância fundamental para os rumos futuros da transição. O preço pela não apuração do ocorrido foi um acordo tácito do governo com a linha dura no sentido de que esse tipo de ação seria suspensa. Estabelecia-se aqui um "contrato" através do qual as Forças Armadas, particularmente o Exército, em função do ocorrido, não seriam expostas a um julgamento público, e, em contrapartida, os duros, inconformados com os rumos da transição, não questionaram mais o regime através da subversão (D’Araujo, 2000, p. 7).

De forma semelhante a que entrou no governo, o último governo militar encerrou o ciclo de 21 anos ininterruptos no poder sem maiores confrontos armados com a sociedade civil. Desgastado pelas inúmeras denúncias de abusos contra membros da sociedade, entre elas assassinatos e tortura no decorrer do regime militar, e por uma forte crise econômica iniciada na segunda metade da década de 1970, os militares foram projetando sua saída desde o governo Geisel. Entre idas e vindas, os governos militares prepararam, através de negociações com a oposição, representada pelo MDB, a famosa transição "lenta, gradual e segura". As eleições presidenciais indiretas ocorridas em janeiro de 1985 corroboraram para isso.

Político vinculado ao partido de apoio do regime militar por vários anos (a Aliança Renovadora Nacional), o candidato à vice-presidência, José Sarney assumiu a presidência da República, interinamente, no dia 15/03/1985, pois o candidato eleito, Tancredo Neves, adoeceu e não chegou a assumir o cargo. Com a morte de Tancredo em 21/04/1985, pairou sobre o ambiente político brasileiro a possibilidade de estar ocorrendo uma situação ilegal referente à posse de Sarney, haja vista que não poderia assumir em definitivo a presidência, pois o presidente eleito não recebeu a faixa. O político maranhense recebeu apoio por parte dos militares em detrimento da possibilidade do então presidente da Câmara dos Deputados, Ulysses Guimarães, desafeto das Forças Armadas, receber esse posto. Em depoimento, o ministro do Exército durante o governo Collor, general Carlos Tinoco Ribeiro Gomes, ilustrou o desenho desse apoio:

Aí, o general Leonidas pegou a Constituição, foi para uma reunião dos ministros com o Sarney e mostrou que o normal seria o vice-presidente assumir. Havia quem achasse que não, porque o Tancredo não tinha assumido, mas a palavra dele dirimiu as dúvidas (Castro, D’Araujo, 2001, p. 76).

A participação do general Leonidas significou uma determinada liderança na transição política, pois o próprio vice-presidente possuía dúvidas acerca do apoio político ao assumir, eventualmente, a Presidência. A partir da análise de um major do Exército, a hesitação de Sarney contribuiu para enaltecer a figura de Leonidas e o papel dos militares na redemocratização: 
Durante aquela noite, Sarney repetira esse mesmo desejo várias vezes, para mais de um interlocutor: achava que não tinha legitimidade para assumir, julgava que se deveria esperar que o presidente eleito Tancredo Neves, internado no Hospital de Base, se recuperasse para tomar posse. Leônidas perdeu a paciência e deu uma bronca naquele que seria o seu comandante a partir do dia seguinte: "Olha, Sarney, você sabe os problemas graves que estamos enfrentando. Você não pode mais criar nenhum caso. Todos estão unânimes nessa decisão." O general terminou, então, de forma definitiva: "Boa noite, presidente!” As Forças Armadas são as fiadoras da Nova República (Freitas, 2008, p. 25).

$\mathrm{O}$ que poderia ter sido um mandato interino transformou-se em um longo mandato de cinco anos e serviu de base para os interesses militares na futura Constituinte, além de propiciar a permanente intervenção em assuntos não relacionados à esfera militar:

No final de 1985, o mapa político se tornou claro: as Forças Armadas haviam deixado o governo mas não o poder. Essa era uma situação excepcional para as Forças Armadas, pois, elas se isentavam de carregar o ônus de governar um país em crise mas mantinham o poder de veto sobre decisões que afetassem seus interesses (Zaverucha, 1994, p. 85).

Prova de que os militares deixaram os postos governamentais, encontra-se na completa desmilitarização dos ministérios. No entanto, os militares mantiveram seu poder decisório logo após o fim do Regime Militar, configurando um quadro tutelar, cujos interesses da corporação castrense muitas vezes prevaleciam em contraposição ao pulverizado poder civil. A tutela empreendida pelos militares no governo Sarney foi mais um pacto político para salvaguardar os interesses dos homens de farda. Ao mesmo tempo em que o primeiro governo civil pós-Regime Militar recebeu apoio da caserna, suas políticas de governo eram restringidas.

Um dos principais retratos dessa situação tutelar foi a participação do Ministro de Exército, o general Leônidas Pires Gonçalves, em vários processos decisórios no governo Sarney, institucionalizando, frequentemente, suas opiniões acerca dos problemas nacionais (Miyamoto, 2000). O general tutelou muitas ações empreendidas pelo governo, sociedade e Congresso Nacional, distanciando, ainda mais o poder político e o aparelho militar. Houve intromissões na política externa ao afirmar que o Brasil construiria a arma nuclear caso suspeitasse que a Argentina, então parceira no processo de formação do Mercosul, estivesse planejando sua construção. Internamente, advertiu membros políticos a abrigarem as propostas militares na Constituição, entre elas, a conservação do regime presidencialista contra a proposta a favor do parlamentarismo. Seu posicionamento foi decisivo na conservação do processo político iniciado no governo Geisel, ao preparar o terreno e manter prerrogativas e privilégios militares na nova Constituinte, a qual deveria refletir o momento político à luz do novo sistema político democrático.

A atuação dos militares no apoio ao Congresso Constituinte em contraposição aos setores mais progressistas, que defendiam a criação de uma Assembleia de representantes eleitos pela sociedade, revelou mais uma vez o peso decisório que ainda possuíam após o fim do Regime Militar. Com isso, a Assembleia Constituinte foi formada por deputados federais e senadores vitoriosos nas eleições 
passadas. Durante os anos de 1987 e 1988 houve os trabalhos para a construção dos documentos. Esse momento foi marcado pela disputa entre as forças políticas conservadoras e o governo federal organizados em suas posições e os movimentos sociais progressistas defensores da democracia. Antes desse debate já ilustramos o papel interventor de lideranças militares, entre elas, a do ministro do Exército, na sustentação de seus interesses na nova Carta. Um dos fortes apoios dados a essa ala conservadora veio do poder Executivo:

O presidente José Sarney participou deste jogo de pressões com relação à Assembléia Nacional Constituinte, acrescentando-lhes suas próprias razões de natureza política às pressões de natureza militar, subordinando-se à lógica e aos interesses castrenses, mais perenes do que a provisória e cambaleante Aliança Democrática. Os interesses militares seriam ainda mais perenes do que os interesses políticos do país, não devendo, portanto, constranger-se ao estrito cumprimento da legalidade constitucional (Oliveira, 1994, p. 120).

A presença militar no que tange a interferência na política do país permaneceu após o Regime Militar. Podemos constatar dessa presença, a continuação dos assuntos ligados à defesa e segurança no país sob as mãos das instituições castrenses, além de preservarem para si a histórica visão militar de guardiões da República brasileira. Ou seja, notamos uma situação paradoxal na formação da Nova República no Brasil: dentro de um sistema democrático, a gerência de políticas, as quais deveriam girar em torno dos interesses de toda a sociedade, permaneceu restringida basicamente aos interesses de um pequeno grupo desse conjunto. Além dos controles nessas duas esferas, os militares trabalharam para manter certos privilégios de carreira, combateram a reforma de ampliação dos direitos da Lei de Anistia de 1979, e entre outros arranjos, costuraram sua autonomia na Nova República.

\section{O legado do autoritarismo no Brasil e no Chile}

O aparato repressor estabelecido no governo Pinochet foi avassalador, devastando não apenas milhares de vidas, mas aniquilando todo um sistema político e social. O neoliberalismo não ficou restrito a algumas reformas econômicas, mas tomou conta de toda uma organização social. Diante da inclusão dessa concepção de mundo aliada a um forte personalismo centrado na figura de Pinochet, a maneira como o Chile realizaria seu processo de transição à democracia marcaria também a preservação de diversos mecanismos autoritários no novo sistema democrático, diferenciando-se, inclusive, de seu exemplo mais próximo na América do Sul:

No Brasil, o caso na região que mais caraterísticas próximas teve com a experiência chilena, não existiam grandes dificuldades para a reforma de sua constituição como ocorreu no Chile. Pinochet, em última análise, tinha deixado as coisas verdadeiramente "atadas y bien atadas", acima até do que havia feito Franco na Espanha, embora este caso também tenha se notabilizado por sua caracterização personalista (Agüero, 2006, p. 318). 
Transcorridos os anos de Pinochet no poder, o processo de controle civil sobre as Forças Armadas manteve-se extremamente restrito. As autonomias analisadas no processo de redemocratização brasileiro destoam do processo chileno quando pensamos na figura central de Pinochet, que se manteve à frente do Exército após o fim do regime ditatorial. Marcadamente personalista, o regime de Pinochet assegurou, entre diversas prerrogativas, o controle de uma considerável receita destinada à Defesa chilena. Enquanto comandante em chefe do Exército, Pinochet permaneceu por mais oito anos depois de 1990. Carlos Huneeus aponta um grave elemento interruptor do processo democrático no Chile, quando o ex-ditador "intervino en la arena política para defender los intereses del Ejército, especialmente para impedir que el gobierno del presidente Aylwin llevara adelante la política de verdad y justicia por los atropellos a los derechos humanos, con actos que llegaron al límite de la legalidad” (Huneeus, 2014, p. 181).

Os limites da legalidade apontados por Huneeus podem ser descritos em episódios subsequentes ao processo de redemocratização, datados no início dos anos 1990. Em dezembro, o governo do presidente Patricio Aylwin, primeiro governo civil após dezessete anos de ditadura, resolveu encurtar o período de permanência do general Pinochet no comando do Exército, após denúncias de corrupção envolvendo o filho do ex-ditador. A intenção era fazer com que Pinochet renunciasse entre os meses de março e abril de 1991, prazo este considerado inaceitável pela cúpula militar. Iniciou-se um movimento conhecido como "ejercicio de enlace". Tratou-se de uma demonstração de força por parte dos militares, embora as Forças não tenham reconhecido que havia ocorrido um aquartelamento. A versão castrense sustentou que havia se tratado de um rotineiro "ejercicio de alistamiento y enlace", termo esse não presente nos manuais militares daquele período (Calbún, 2012, p. 20). O Executivo aceitou tal versão. Diversos líderes militares e policiais prestaram solidariedade a Pinochet, tanto através de mensagens quanto por meio de demonstrações de força ao redor do general.

A pressão exercida se fez valer. Em janeiro de 1991, foi divulgado um informe da comissão de investigação parlamentária, que não fazia nenhuma menção à participação de Pinochet nesse processo. Para Carina Calbún Mansilla, o "ejercicio de enlace" representou uma ameaça, mas o governo de Aylwin optou por não dar sequência às investigações que envolveriam a figura de Pinochet, em detrimento de não por em risco sua estratégia global de transição e sua tática de manter uma boa relação com as Forças Armadas (Calbún, 2012, p. 21).

Essa polêmica, entretanto, voltaria ao radar da crise política pós-transição no Chile, dois anos depois. Após declarar em agosto de 1991, que a transição rumo à democracia estava concluída, o presidente Aylwin teve que reconsiderar tal afirmativa. As impunidades adjacentes ao período ditatorial e a posição reativa dos grupos que atuavam no regime de Pinochet dificultavam a tentativa de equilíbrio e pacificação dos discursos na esfera política.

Outro evento conflituoso entre governo civil e Forças Armadas foi a discussão acerca da Lei de Anistia, promulgada em 1978. No primeiro artigo deste documento,

Concede-se a anistia a todas as pessoas que, em qualidade de autores, cúmplices ou encobridores tenham incorrido em atos criminosos, durante a vigência da situação do estado de sítio, entre 11 de setembro de 1973 e 10 de março de 1978, não se encontrando atualmente submetidas a processo ou condenadas (Chile, 1978). 
Seguindo uma lógica similar à lei brasileira, os autores desta lei alegavam promover uma reconciliação após anos de radicais e violentas polarizações. Porém, o resultado esperado não teve o mesmo efeito. As tensões não foram amainadas, posto que não havia um critério único para aplicar a Lei de 1978 e as amarras costuradas pelo governo militar impediam qualquer avanço significativo no que diz respeito à realização da Justiça. Embora muitas dessas questões tenham enfraquecido o desenvolvimento de uma construção democrática nas relações civis-militares chilenas, alguns apontamentos positivos podem ser detectados como a criação da Comissão Nacional de Verdade e Reconciliação, responsável pela revelação de grande quantidade de crimes, que auxiliaram em diversos casos de luta pela memória (Calbún, 2012, p. 16) . $^{4}$

O estopim da crise nas relações civis-militares chilenas pós-redemocratização, contudo, ocorreu em 1993. No dia vinte e dois de maio daquele ano, o presidente Patricio Aylwin iniciou uma viagem internacional, que iria até o começo de junho. Seis dias depois que o mandatário partiu de Santiago, um incomum movimento militar teve início em ruas próximas ao edifício das Forças Armadas, quando se realizava uma reunião presidida pelo general Pinochet. $\mathrm{O}$ episódio ficou conhecido como "Boinazo", pois os militares utilizaram boinas negras na suspeita operação. Havia ali uma preocupação por parte da instituição militar chilena quanto a uma grande quantidade de problemas e situações consideradas intoleráveis. Outros prédios militares também foram reforçados na capital Santiago e na cidade de Valparaíso. Segundo Carina Calbún, as versões acerca do que ocorreu no dia 28 de maio foram inicialmente contraditórias (Calbún, 2012, p. 23). Por parte do Exército, suas primeiras declarações afirmaram que se tratava de um exercício presente dentro de um cronograma de planejamento de atividades. Por outro lado, o presidente Aylwin, mesmo estando no exterior, declarou não ser razoável que o edifício do ministério da Defesa ou qualquer outra unidade esteja rodeado por tropas militares. Subjaz desses desencontros algo desconexo nas relações civis-militares daquele momento.

As declarações não amainaram os ânimos, sendo que diversos grupos políticos, de diferentes vertentes, pressionaram para que se tivesse uma investigação mais profunda em torno do acontecido. As tensões se exarceberam quando o ministro do Interior, Enrique Kraruss, declarou que "las relaciones entre el gobierno y el Ejército siguen tensas... el gobierno espera una nueva declaración militar en torno al estado de alerta en que se encuentra la institución castrense desde que se produjo un inusual reforzamiento" (Krauss apud Calbún, 2012, p. 23). Configurou-se nesse instante um impasse entre governo e Forças Armadas, quando Krauss e Pinochet se reuniram e o general pressionou o ministro para que este assinasse uma ata de acordo referente a algumas medidas que protegessem sua figura e respaldasse os interesses dos militares. Krauss não aceitou o compromisso.

Destaquei até aqui os principais problemas enfrentados pela sociedade chilena em relação ao controle civil sobre os militares no início dos novos regimes democráticos pós-ditadura pinochetista. Uma das maneiras de interpretar as dificuldades no caso chileno também está relacionado, assim como na trajetória brasileira, ao fato de os militares participarem ativamente do processo de redemocratização:

Na medida em que as forças armadas foram as principais protagonistas da transição e que se atribuíram a si mesmas um importante papel quando deixassem o governo,

\footnotetext{
${ }^{4}$ Em 2008, a Lei de Anistia seria revogada.
} 
elas ficaram expostas diretamente aos aspectos mais conflituosos da política quando esta reiniciou-se sem restrições em 1990 (Agüero, 2005, p. 318).

A permanência de Pinochet motivou diversos desses conflitos apontados acima, pois sua liderança impedia que o controle civil avançasse. Felipe Agüero destaca que as disputas pela delimitação do poder e o modo como este seria exercido na prática, levando em consideração as tensões existentes no tratamento aos problemas derivados das violações aos direitos humanos, entre outros aspectos, centralizaram o papel das Forças Armadas nesse processo. Tudo isso tinha o respaldo da Constituição de 1980, dado o poder e a independência dos altos cargos militares em detrimento do poder de ação do Executivo. As leis orgânicas constitucionais terminaram sendo decididas exclusivamente pelos militares antes da transição de poder. Para Felipe Agüero, este aspecto não consensual da transição chilena definiu boa parte do que seriam as turbulências na nova democracia (Agüero, 2005, p. 322).

No caso brasileiro, a maneira como foi conduzida a redemocratização no país também trouxe consequências ruins para o processo de controle civil sobre a Defesa no país. A partir da famosa transição "lenta, gradual e segura", os militares puderam manter suas prerrogativas do período em que estiveram no poder e assegurar suas posições (no governo Sarney essas posições foram totalmente garantidas). Aliada a manutenção dos privilégios, as Forças Armadas conseguiram preservar seus direitos sobre a tutela da sociedade, ao conservarem a garantia da lei e da ordem na Constituição de 1988. Evidente, que esses direitos não foram mantidos e conquistados sem o apoio de boa parte do grupo político, que participou do processo de formulação da carta "democrática". Além desse apoio de grande parte da elite política do país, os militares contaram com a leniência da sociedade civil, que assistiu pacificamente a não possibilidade de poder decidir sobre as questões de Defesa no emergente regime democrático (sem a presença de um Ministério da Defesa, o controle sobre o orçamento das Forças e as decisões sobre o que é relevante para a Defesa do Brasil, mantiveram-se no interior das instituições castrenses). Passados os primeiros governos civis da Nova República, percebemos que houve avanços na questão do controle civil sobre os militares na área da Defesa. Todavia, mesmo com a criação da Secretaria de Assuntos Estratégicos (SAE), a implementação das políticas de defesa e a construção do Ministério da Defesa (1999) não colocaram em extinção os movimentos políticos militares que sempre influenciaram na República brasileira.

\section{Referências}

AGGIO, Alberto. Um lugar no mundo: estudos de história política latino-americana. Rio de Janeiro/Brasília: Contraponto/Fundação Astrojildo Pereira, 2015.

. Chile: Processo político e controvérsias intelectuais. Lua Nova, n. 49, p. 87-111, 2000.

. Pensamento político e estratégias democráticas na América Latina. Tese de Livre

Docência. Universidade Estadual Paulista, 1999.

AGÜERO, Felipe. Democratización y militares: breve balance de diecisiete años desde la transición. In: RODRÍGUEZ, Letícia M. R.; ALCÁNTARA, Manuel S. (Orgs.). Chile: política y modernización democrática. Barcelona: Edicions Bellaterra, 2006. 
. Democratización y militares: breve balance de diecisiete años desde la transición. In: RODRÍGUEZ, Letícia M. R.; ALCÁNTARA, Manuel S. (Orgs.). Chile: política y modernización democrática. Barcelona: Edicions Bellaterra, 2005.

ALVES, José Eustáquio Diniz. O encolhimento e o empobrecimento relativo da América Latina [Online]. Disponível em: https://www.ecodebate.com.br/2019/06/14/o-encolhimento-e-oempobrecimento-relativo-da-america-latina-artigo-de-jose-eustaquio-diniz-alves/. Acesso em: 15 jun. 2019.

BERSTEIN, Serge. Culturas políticas e historiografia. In: AZEVEDO, Cecília et al. Cultura política, memória e historiografia. Rio de Janeiro: FGV, 2009.

BRASIL. Constituição da República Federativa do Brasil. Brasília: ANC, 1988.

CALBÚN, Carina M. El “Boinazo” de 1993: desde la percepción de un militar puntarenense. Dissertação de Mestrado. Universidad de Magallanes, 2012.

CASTRO, Celso; D’ARAUJO, Maria Celina (Orgs.). Militares e política na Nova República. Rio de Janeiro: FGV, 2001.

CHILE. Decreto Ley n. 2191. Santiago de Chile: Diário Oficial, 1978.

COELHO, Edmundo C. Em busca de identidade o Exército e a politica na sociedade brasileira. Rio de Janeiro: Record, 2000.

D’ARAUJO, Maria Celina. Ainda em busca de identidade: desafios das Forças Armadas na Nova República. Rio de Janeiro: CPDOC, 2000.

D’ASSUNÇÃO BARROS, José. História Comparada. Petrópolis: Vozes, 2014.

FGV CPDOC. O golpe de 1964 [Online]. Disponível em:

https://cpdoc.fgv.br/producao/dossies/FatosImagens/Golpe1964. Acesso em: 15 jun. 2019.

FREITAS, O. R. de. J. A participação política dos ministros do Exército de 1964 a 1985. Trabalho de Admissão ao Curso de Ciências Militares. Escola de Comando e Estado-Maior do Exército, 2008.

GARRETÓN, Manuel A. M. A redemocratização no Chile: transição, inauguração e evolução. Lua Nova, n. 27, p. 59-92, 1992.

. La posibilidad democrática en Chile. Santiago de Chile: Flacso, 1989.

GUMBRECHT, Hans Ulrich. Depois de 1945: latência como origem do presente. São Paulo:

Editora Unesp, 2014.

HUNEEUS, Carlos. La democracia semisoberana: Chile después de Pinochet. Santiago de Chile: Taurus, 2014.

HUNTINGTON, Samuel. A Terceira Onda: a democratização no final do século XX. São Paulo: Ática, 1994.

KRAUSS, Enrique. A plena voz: Crónicas. Santiago de Chile: Renacimiento, 1997.

MIYAMOTO, Shiguenoli. A política de Defesa brasileira e a Segurança Regional. Contexto Internacional, v. 22, n. 2, p. 431-472, 2000.

OLIVEIRA, Eliézer R. de. De Geisel a Collor: Forças Armadas, transição e democracia. Campinas: Papirus, 1994.

PINHEIRO, Paulo S. Autoritarismo e transição. Revista USP, n. 9, p. 45-56, 1991. 
SANTOS, Maria Helena de Castro. A nova missão das Forças Armadas latino-americanas no pósGuerra Fria: o caso do Brasil. Revista Brasileira de Ciências Sociais, v. 19, n. 54, p. 107-128, 2004.

VALENZUELA, J. Samuel. La Constitución de 1980 y el inicio de la redemocratización en Chile. Notre Dame: Kellogg Institute, 1997.

ZAVERUCHA, Jorge. Rumor de Sabres: controle civil ou tutela militar? São Paulo: Ed. Ática, 1994.

Artigo recebido em: Abril/2019

Artigo aprovado em: Junho/2019

Victor Augusto Ramos Missiato (victor_missiato@hotmail.com) é Doutor em História pela Universidade Estadual Paulista (UNESP)/Franca.

\title{
Forças Armadas, Autonomias e Autoritarismo: a atuação das Forças Armadas de Brasil e Chile nas transições rumo à democracia
}

Resumo. Neste artigo procuramos apresentar uma análise comparada entre os processos de transição política pós-regimes militares no Brasil e no Chile. Partindo do pressuposto de que ambas transições ocorreram de forma incompleta, pois os legados do autoritarismo e as preservações de autonomias, por parte das Forças Armadas, mantiveram-se presentes durante todo o processo de transição, objetivamos apresentar o modo como tais medidas foram introduzidas e pressionadas pelas Forças Armadas no decorrer das negociações políticas com as forças civis. Para isso, utilizamos uma análise acerca dos processos constitucionais de cada país, bem como ações de lideranças militares naquele período.

Palavras-chave: Forças Armadas; Transição; Democracia.

\section{Armed Forces, Autonomies and Authoritarianism: the action of Brazil's and Chile's Armed Forces on the transitions to democracy}

\begin{abstract}
In this article we seek to present a comparative analysis between the process of political transition dictatorship-democracy in Brazil and Chile. On the assumption that both transitions took place, in incomplete form as the legacies of authoritarianism and the preservation of autonomy on the part of the armed forces, remained present throughout the transition process, aim to present the how such measures were introduced and pressed by the military during the political negotiations with the civilian forces. For this, we use an analysis about the constitutional processes of each country, as well as actions of military leaders at the time.
\end{abstract}

Keywords: Armed Forces; Transition; Democracy. 